University of Louisville

ThinkIR: The University of Louisville's Institutional Repository

Faculty Scholarship

2013

\title{
Civic education and democratic capacity : how do teachers teach and what works?
}

\author{
Allison M. Martens \\ University of Northern lowa \\ Jason Gainous \\ University of Louisville, jason.gainous@louisville.edu
}

Follow this and additional works at: https://ir.library.louisville.edu/faculty

Part of the Curriculum and Instruction Commons, and the Political Science Commons

\section{Original Publication Information}

This is the peer reviewed version of the following article:

Martens, Allison M. and Jason Gainous. "Civic Education and Democratic Capacity: How Do Teachers Teach and What Works?" 2013. Social Science Quarterly 94(4): 956-976.

which has been published in final form at 10.1111/j.1540-6237.2012.00864.x. This article may be used for non-commercial purposes in accordance with Wiley Terms and Conditions for Self-Archiving.

This Article is brought to you for free and open access by ThinkIR: The University of Louisville's Institutional Repository. It has been accepted for inclusion in Faculty Scholarship by an authorized administrator of ThinkIR: The University of Louisville's Institutional Repository. For more information, please contact thinkir@louisville.edu. 


\title{
Civic Education and Democratic Capacity: How Do Teachers Teach and What Works?*
}

\author{
Allison M. Martens, University of Northern Iowa \\ Jason Gainous, University of Louisville
}

Objectives. In recent years, political scientists have found that civic education improves the democratic capacity of students, yet little research has been done to date on how and why civic education works when it does. In this study, we go inside the classroom to explore how teachers teach civics to find out what works best at preparing young people for responsible, democratic citizenship. Methods. Using a survey of American students, principals, and teachers, we examine the varied instructional methods being employed by social studies teachers in ninth-grade classrooms across the country to determine which methods and which combinations of methods do the best job of enhancing students' democratic capacity defined as their political knowledge, political efficacy, and intent to vote. Results. Our results suggest that there are four broad teaching approaches employed by social studies teachers: traditional teaching, active learning, video teaching, and maintenance of an open classroom climate. Teachers may employ some combination of these approaches. The analysis indicates that approaches that foster an open classroom climate (encouraging student input) in combination with the others tend to be the most fruitful across the board. While any combination including an open classroom climate maximizes benefit, traditional teaching (i.e., use of methods including textbook reading, worksheets, memorization, and so forth) combined with an open classroom climate seems to do the best. Also, the results suggest that the combinations that work best for stimulating internal efficacy vary greatly from those stimulating the other citizenship outcomes. Conclusions. Taken together, our results suggest that fostering an open classroom climate when teaching civics is the surest way to improve the democratic capacity of America's youth. Further, teachers should be attentive to the instructional tradeoffs necessary to creating student capacities for both active and informed citizenship.

In May 2011, the National Assessment of Educational Progress (NAEP) released the Nation's Report Card in Civics. The results were disappointing, with more than three-quarters of 12 th graders and nearly 80 percent of 8 th graders scoring below the proficient level on the national assessment. In fact, high school seniors, the nation's newest voters, lost ground, as the average

*Direct all correspondence to Jason Gainous, Department of Political Science, University of Louisville, Ford Hall Rm. 203, Louisville, KY 40292 〈jason.gainous@louisville.edu〉. Jason Gainous will share all data and coding for replication purposes. Both authors contributed equally to this study. 
score for this group declined between the 2006 and 2010 exams (NCES, 2011). This sobering news on the state of civic education in America was met with a flurry of media attention and concerned commentary by policymakers. Former U.S. Supreme Court Justice Sandra Day O'Connor called the results "dismal," and urged renewed commitment to civic education for America's youth, reminding Americans that " $[\mathrm{k}]$ nowledge of our system of government is not handed down through the gene pool. The habits of citizenship must be learned, and our public schools were founded to educate students for democratic participation" (O'Connor, 2011). Hers is a common refrain, as America's public officials have pointed to the importance of civic education to the mission of public schools since our nation's founding (Kaestle and Foner, 1983). The American public agrees, frequently ranking the preparation of students for responsible, democratic citizenship as the most important purpose of public schools (Crabtree, 2005; Rose and Gallup, 2000:47). Widespread agreement is also found among educators, who view citizenship training as the primary purpose of a social studies curriculum (Thornton, 1994).

Yet, political scientists had long dismissed civic education in America's schools as ineffective and largely abandoned its study (Beck, 1977; Langton and Jennings, 1968; Merelman, 1971; Robinson et al., 1966; Somit et al., 1958). Starting with Niemi and Junn's landmark study in 1998, however, political scientists have since restarted their inquiry, finding that civic education in fact works, improving not only students' political knowledge, but also their political efficacy and intent to later become voters (Campbell, 2007, 2008; Conover and Searing, 2000; Feldman et al., 2007; Gainous and Martens, 2012; Gimpel, Lay, and Schuknecht, 2003; Hartry and Porter, 2004; Macedo, 2000; McDevitt and Kiousis, 2006; Niemi, Hepburn, and Chapman, 2000; Pasek et al., 2008; Turnbull et al., 2007; Vercellotti and Matto, 2010). ${ }^{1}$ However, given the generally low levels of political knowledge and efficacy of young people evidenced in the most recent Nation's Report Card and other studies, we know that civic education may be working but clearly not nearly well enough (Delli Carpini, 2000; Delli Carpini and Keeter, 1996; Torney-Purta, 2002). For America's schools to do a better job building young citizens, however, policymakers and educators need to know what works in the classroom when it comes to civics instruction. While interest among political scientists in civic education has been renewed, and the value of civics instruction at least somewhat vindicated, we still know very little about how and why civic education works when it does.

\footnotetext{
${ }^{1}$ To be precise, civic education works for students who come from less rather than more privileged backgrounds (Gainous and Martens, 2012). Given the concern by many that our most socially and economically vulnerable students are clustered in dysfunctional schools that lack the positive spillover effects of a high SES peer group, the fact that teaching nonetheless matters for these students when it comes to building citizenship is welcome news (Godwin and Kemerer, 2002). In this study, we explore ways to maximize those positive teaching effects through pedagogy.
} 
In this study, we go inside the classroom to explore how teachers teach civics to find out what works best at preparing young people for responsible, democratic citizenship. Using a survey of American students, principals, and teachers, we examine the varied instructional methods being employed by social studies teachers in ninth-grade classrooms across the country to determine which methods and which combinations of methods do the best job of enhancing students' democratic capacity defined as their political knowledge, political efficacy, and intent to vote. Our results suggest that there are four broad teaching approaches employed by social studies teachers: traditional teaching, active learning, video teaching, and maintenance of an open classroom climate. Teachers may employ some combination of these approaches. The analysis indicates that approaches that foster an open classroom climate (encouraging student input) in combination with the others tend to be the most fruitful across the board. While any combination including an open classroom climate maximizes benefit, traditional teaching (i.e., use of methods including textbook reading, worksheets, memorization, etc.) combined with an open classroom climate seems to do the best. Also, the results suggest that the combinations that work best for stimulating internal efficacy vary greatly from those stimulating the other citizenship outcomes.

\section{Classroom Effects and Civic Education}

Despite research demonstrating the effectiveness of civic education, little work has been done to date on what specific forms of civics instruction work best, particularly, civics instruction in the classroom, as much of the recent research undertaken on civic education and citizenship has tested the effectiveness of service learning that takes place largely outside school (Billig, Root, and Jesse, 2005; Hart et al., 2007; Kahne, Chi, and Middaugh, 2006; Kahne and Sporte, 2008; Kahne and Westheimer, 2006; Niemi, Hepburn, and Chapman, 2000; Youniss and Yates, 1997). As for the classroom, we know that the frequency of exposure to civics instruction, as well the range of civics topics covered in class, including the use of specialized civics curriculum such as the Center for Civic Education's We the People, are important to improving students' democratic capacity, particularly the accumulation of political knowledge (Gainous and Martens, 2012; Hartry and Porter, 2004; Niemi and Junn, 1998; Turnbull et al., 2007). Less time has been spent, however, examining classroom effects, often because measures of pedagogy available to researchers on national surveys and assessments are relatively thin (Niemi and Junn, 1998). So we know what teachers should be teaching and how often, but we know relatively little about how teachers should actually go about teaching their curriculum.

This lack of information on social studies teaching is a long-standing problem. Very little empirical work has been done, even among education researchers, to assess what actually happens in the social studies classroom 
(Cuban, 1991). The limited available research suggests that social studies teachers in secondary classrooms most commonly rely on traditional teachercentered methods of instruction, such as lecture, recitation (discussion), tests, and individual seatwork, such as worksheets or textbook reading, with these instructional patterns remaining quite stable over time (Cuban, 1991; Thornton, 1994). Updated research would be useful to determine whether, despite recent changes in curriculum and technology, most teachers today continue to teach according to the traditional model.

Among political scientists who have focused on social studies pedagogy, classroom discussion of current events and political issues has been most commonly studied to determine its benefits. Political discussion has long been linked to increased political efficacy and the fostering of democratic norms, so it is unsurprising that political scientists would be drawn to testing, and confirming, its effectiveness in the classroom (Almond and Verba, 1963; Andolina et al., 2003; Campbell, 2007, 2008; Ehman, 1980; Feldman et al., 2007; Gainous and Martens, 2012; Hahn, 1998; Hess and Posselt, 2002; McDevitt and Kiousis, 2006; Niemi and Junn, 1998; Pasek et al., 2008; Torney-Purta, 2002; Vercellotti and Matto, 2010).

While classroom discussion of current events has traditionally been an instructional feature of the social studies classroom, recently, political scientists have begun to concentrate on more robust approaches to classroom discussion as an instructional tool in their studies, focusing on classroom environments where students are exposed to political discourse and debate by being encouraged to share their views. Often referred to as an open classroom climate, this pedagogical approach models the rough and tumble of participatory democracy, training students to appreciate conflicting viewpoints and engaging them at an early age in both political processes and political ideas (Hess, 2004; Hibbing and Theiss-Morse, 1996, 2002). In an open classroom, students, through the valuing of their input, are empowered to develop a familiarity with politics and a confidence in their views that normalizes political engagement (Youniss and Yates, 1997). Campbell $(2007,2008)$ has convincingly demonstrated that maintenance of an open classroom climate significantly improves all elements of democratic capacity (knowledge, efficacy, and voting intent), a finding confirmed by Gainous and Martens (2012), but the relationship of this pedagogical approach to other instructional methods typically employed in social studies classrooms remains obscure, as does the popularity of its use. Educators would clearly benefit from further empirical research about the relative effectiveness of this approach to teaching civics.

Despite the continued dominance of traditional teaching methods in social studies classrooms, a pattern of student-centered instruction, including the use of active learning techniques, began to develop in the late 20th century, and continues to grow in popularity (Cuban, 1991). Active learning, which is believed to improve student motivation over and above passive forms of traditional instruction, requires that students directly engage in meaningful learning activities where they think about what they are doing as they proceed 
(Bonwell and Eison, 1991; Silberman, 1996; Zmuda, 2008). Some practitioners have argued that active learning techniques may be especially appropriate for the social studies classroom, given that student-centered learning may best model democratic citizenship (Thornton, 2005; Woolever and Scott, 1988). Typical instructional techniques that center on the student include role-playing and simulations, classroom debates, peer-guided discussion, cooperative learning, research projects, letter writing, volunteerism, and guest speakers that engage students directly with government or the community, and researchers have found that many of these active learning techniques provide at least some added value over passive forms of civics instruction in building democratic capacity (Billig, Root, and Jesse, 2005; Kahne, Chi, and Middaugh, 2006). Given these positive results, and the salience of student-centered learning to citizenship building, it would be helpful to know whether adoption of active learning techniques is widespread in America's social studies classrooms.

Although it would be reasonable to assume that complementing traditional forms of instruction with active learning techniques in the social studies classroom would improve democratic outcomes, Gainous and Martens (2012) found that the proliferation of teaching techniques employed in civics instruction actually had negative effects on political knowledge. As teachers diversified their instructional methods, in keeping with currently popular recommendations by education practitioners for accommodating classrooms of diverse learners, students actually learned less about civics. This finding suggests that isolating the most effective instructional methods or combinations of methods is critical to allowing teachers the selectivity needed to maximize knowledge building in their classroom. However, despite the negative effects on political knowledge, Gainous and Martens (2012) also found that instructional variation actually stimulated students' political efficacy, meaning that teachers who diversified their instructional techniques succeeded in creating young citizens who were potentially more politically confident and active, even if less well informed. Thus, more was not less in terms of political efficacy. These differential classroom effects on democratic capacity are not necessarily surprising given that the mechanisms influencing student motivation and rote learning may be distinct (Benware and Deci, 1984). As such, teachers would greatly benefit from knowing which instructional methods best improve knowledge, efficacy, and participation so that they can make informed choices about how to treat this instructional tradeoff in building citizenship.

Another tradeoff in the effectiveness of civics instruction has also been identified by researchers who study political efficacy and civic education, pointing to the differences between how civic education operates on political efficacy's two aspects (Junn, 2004; Kahne and Westheimer, 2006). Divided between an internal component, an individual's confidence in his or her ability to understand and navigate politics, and an external component, an individual's beliefs in the responsiveness of government to citizens' demands, that are quite distinct, the possibility that civics instruction might have differing effects on each component of political efficacy is not surprising 
(Balch, 1974; Converse, 1972). Indeed, Kahne and Westheimer (2006) have urged schools to pay particular attention to the development of students' internal efficacy in designing their civics curriculum. In light of the low level of political motivation in today's youth, coupled with the significance of adolescent development of political efficacy to political engagement, this prescription seems wise, making it worth our while to identify those teaching techniques that best stimulate internal efficacy (Delli Carpini, 2000; Easton and Dennis, 1969; Hess and Torney-Purta, 1967; Jennings and Niemi, 1974, 1981; Lopez et al., 2006; Niemi and Sobieszek, 1977; Youniss and Yates, 1997). Furthermore, focus on internal efficacy as opposed to external efficacy in civic education avoids the potential problem of creating unreasonable or unfounded expectations by students of government responsiveness to their needs (Junn, 2004; Kahne and Westheimer, 2006).

To summarize, our goal in this study is to fill in key gaps in the empirical understanding of how civic education is actually taught in America's classrooms, and which teaching approaches are most effective. We do so by mapping the instructional methods being employed by ninth-grade social studies teachers, and then testing those instructional methods for their effectiveness in stimulating students' democratic capacity defined as their political knowledge, political efficacy, and intent to vote. Put simply, we will answer two straightforward but important questions. How do teachers teach civics? And what works best?

\section{Data and Measurement}

The data used here come from a study conducted by the International Association for the Evaluation of Educational Achievement (IEA) in 1999. Students, teachers, and principals were administered a survey (2,811 students across 124 public and private schools nationwide). The students were in the ninth grade, the grade in which most 14 year olds were enrolled at the time of the assessment. These students had civic education to varying degrees. Additionally, their teachers and principals were surveyed, making a total of three data sets. We merged the teacher and principal data with the student data to add two contextual variables (i.e., each student from the same class was assigned the same value based on the responses of their respective teachers and principals across several variables described below). There were 2,615 usable cases after imputing because some of the teachers did not respond. ${ }^{2}$ While these data are getting a bit dated, we believe they are still useful because instructional methods have not fundamentally changed

\footnotetext{
${ }^{2}$ We chose not to impute these cases because it would have replaced values for entire classes of students. We did impute the remaining missing values maximizing sample size and increasing the accuracy of our estimates in the process. Little's MCAR test indicated that the student data were not missing completely at random $(p<0.001)$ nor were the combined teacher and school data $(p<0.001)$. Thus, list-wise deletion may have biased our estimates. We replaced
} 
since 1999. That said, there is some evidence from the 2006 Civic and Political Health Survey (CPHS) conducted by the Center for Information \& Research on Civic Learning and Engagement suggesting that the use of an open classroom approach has increased. ${ }^{3}$ This only bolsters our key finding that maintenance of an open classroom climate is the most fruitful approach to teaching civics, because the effects we estimate are likely conservative estimates of what we may see if teachers are indeed more likely to use this approach now.

After offering a brief description of student responses to a series of indicators centered on four democratic capacity outcomes (Political Knowledge, External Efficacy, Internal Efficacy, and the Intent to Vote as adults), we use a principal components analysis of the tetrachoric correlation matrix (because we have a series of binary indicators) to extract those instructional methods that most commonly group together. This analysis allows us to make inferences about the typical approaches teachers are using. We then generate factor scores for each extracted factor. These scores are used to estimate the degree to which students are exposed to each of the different types of methods (Traditional Teaching, Active Learning, Video Teaching, Open Classroom Climate). We then use an ordered-logit procedure to model each of the four democratic capacity outcomes as a function of the four instructional methods factor scores while controlling for the frequency students received social studies instruction (Social Studies Frequency), whether their social studies class focused on civics or government or some other type of social studies (i.e., geography, history, economics, etc.) (Other Social Studies), the range of civics topics covered in said classes (Curricular Breadth), the aggregate socioeconomic status of the school measured as a function of the percentage of students eligible for free lunch (School SES), how civically engaged the students were (Civic Engagement), a series of indicators of ways students may learn and be socialized outside of school (Home Environment), and demographics (Female, Latino, and Black). ${ }^{4}$

Following these models, we estimate a series of ordered-logit models for each democratic capacity outcome as a function of every possible combination of instructional method (i.e., 1. Traditional Teaching and Active Learning, 2. Traditional Teaching, and Open Classroom Climate, 3. Traditional Teaching, Active Learning, and Open Classroom Climate, etc.), while controlling for the methods not used in each respective combination along with the same control

all missing values using the expectation maximization algorithm (Dempster, Laird, and Rubin, 1977). This is a technique that finds maximum likelihood estimates in parametric models for incomplete data (for a complete description, see Little and Rubin, 1987; McLachlan and Krishnan, 1997; Schafer, 1997). After finding the estimates, all variables were centered between 0 and 1 and rounded to the first decimal place $(0.1)$.

${ }^{3}$ For data, see <http://www.civicyouth.org/2006-civic-and-political-health-of-thenation/>.

${ }^{4}$ We describe the operationalization of the instructional method indicators and one of the democratic capacity indicators below in the text. We create dummy variables for self-reported race and gender. All other variables, including the other three dependent variables, are described in the Appendix available at $<$ http://louisville.edu/faculty/j0gain01/my-research/Social Science Quarterly Appendix.pdf>. 
variables specified above. This makes 11 models for each democratic capacity outcome, making a total of 44 models. Each of the 11 possible instructional method combinations was then ranked according to which produced the highest odds ratio. If the effects were not statistically significant $(p \leq 0.05)$, those closer to achieving significance were ranked higher. This allows us to estimate which combinations of instructional methods are most effective for each of the democratic capacity outcomes and if there is a general pattern across the four outcomes.

We measure our first dependent variable, Political Knowledge, using an index constructed from eight items (see Appendix). In each, a multiple-choice question addressing some aspect of U.S. government, including the Constitution, representation, interest groups, the courts, the Bill of Rights, and Congress, was given to respondents. We created dummy variables for each assigning incorrect answers a 0 and correct answers a 1 . These items were then summed. Thus, higher scores represent greater knowledge. The next two dependent variables, also measured using indices, are External Efficacy and Internal Effcacy (see Appendix). The former is based on six questions that tap respondents' attitudes about how well government responds to the will of the people and the latter is based on three items that tap respondents' belief that they do or will have the capacity to influence government personally. Finally, we measure Intent to Vote with a single indicator: When you are an adult, what do you expect that you will do? Vote in national elections (I will certainly not do this, I will probably not do this, I will probably do this, I will certainly do this).

As described above, we use a principal components analysis of the tetrachoric correlation matrix (because we have a series of binary indicators) of all the individual instructional methods items to determine which methods are likely to be employed with each other. These items include the following questions:

- Do you read from your textbook when you study social studies?

- Do you memorize material you have read when you study social studies?

- Do you read extra material not in your textbook (such as newspapers, magazines, maps, charts, or cartoons) when you study social studies?

- Do you fill out worksheets when you study social studies?

- Do you write reports when you study social studies?

- Do you discuss current events when you study social studies?

- Do you watch television shows, videos, or filmstrips in class when you study social studies?

- Do you discuss television shows, videos, or filmstrips when you study social studies?

- Do you take part in debates or panel discussions when you study social studies?

- Do you take part in role-playing, mock trials, or dramas when you study social studies?

- Do you write a letter to give your opinion or help solve a community problem when you study social studies? 
- Do you have visits from people in your community to learn about important events and ideas when you study social studies?

- Students feel free to disagree openly with their teachers about political and social issues during class.

- Students are encouraged to make up their own minds about issues.

- Teachers respect our opinions and encourage us to express them during class.

- Students feel free to express opinions in class even when their opinions are different from most of the other students.

The results indicate that there are clearly four separate factors (see Table 1). This exploratory analysis suggests some conceptual patterns here. Those methods that group together have obvious connections. Thus, we were able to conceptualize each factor and justify creating a factor score for each different type of instructional approach that teachers may employ. Of course, the results here do not mean that teachers employ only one of these types, but rather they suggest that teachers who do one of the things that loads on the respective factor are more likely to do the other things that load on that factor than teachers who do not. Thus, teachers may also employ some combination of these approaches but there is no general pattern to the combined approaches that teachers may employ.

The first, Traditional Teaching, is based on the above items that asked whether the teacher used a textbook, exercises that encouraged memorization, extra material, worksheets, required reports, and discussed current events. These methods all clearly conform to traditional teaching patterns that have long been observed in social studies classrooms, so it is not surprising that they group together. This is one of the most common approaches used by teachers according to their students. Approximately 49 percent of the distribution on the factor score falls in the highest category, meaning that nearly half employ every traditional method according to student reports. The second, Open Classroom Climate, is based on the four items that address whether the teacher encouraged students to make up their own minds and freely express their opinions. This approach provides for student input into the learning process. These items are consistent with earlier research on the effects of an open classroom climate (Campbell, 2007, 2008; Gainous and Martens, 2012). This approach is not as popular as traditional teaching. Only roughly 10 percent of the distribution on this score falls in the highest category, meaning that very few teachers employ every one of these instructional approaches. The third, Active Learning, is based on three items that are typically associated with the developing pattern of student-centered learning in social studies classrooms. These items are use of role-playing, writing letters to officials, and guest visits. Role-playing is clearly active in nature, while letter writing and guest visits engage students with the community, encouraging them to draw connections between themselves and government and envision solutions to political problems. We expected classroom debates and panel discussions to also load on 
TABLE 1

Factor Analysis of Instructional Methods

\begin{tabular}{lcccc}
\hline & Factor 1 & Factor 2 & Factor 3 & Factor 4 \\
\hline Uses textbook & 0.76 & & & \\
Uses memorization & 0.72 & & & \\
Uses extra material & 0.66 & & & \\
Uses worksheets & 0.73 & & & \\
Write reports & 0.77 & & & \\
Discusses current events & 0.72 & & & 0.91 \\
Watch videos/T.V. & & & & 0.86 \\
Discuss videos/T.V. & - & - & - & - \\
Have debates & & & 0.85 & \\
Uses role-playing & & & 0.89 & \\
Students write letters to officials & & 0.76 & & \\
Has guest visits & & 0.79 & & \\
Students feel free to disagree & & 0.77 & & \\
Students make up own mind & & & \\
Teachers respect opinions & & & \\
Students feel free to express opinion & & & & \\
Eigenvalue & & 2.47 & 2.03 & 1.06 \\
$N$ & \multicolumn{2}{c}{2,811} & \\
\hline
\end{tabular}

NOTE: Data come from a 1999 national study conducted by the International Association for the Evaluation of Educational Achievement (IEA). Extraction is based on principal components analysis (varimax rotated) of the tetrachoric correlation matrix. Factor loadings $<0.6$ are suppressed.

this factor, given their active nature and normal association with patterns of student-centered learning but, surprisingly, these methods did not reliably load on any of the factors (they came closest to loading on the traditional teaching factor, 0.57). Active learning is also not as popular as traditional teaching with only approximately 14 percent of the score distribution falling in the highest category. Although these student-centered techniques may currently be in fashion with practitioners, their adoption is not yet widespread in social studies classrooms. Finally, Video Teaching is simply based on the two items that ask whether teachers used videos and had discussions about these videos. We found it interesting that this instructional method stood on its own, and while use of videos as a pedagogical tool may be criticized by many as lazy or poor teaching, there is reason to believe that video teaching can be effective at enhancing democratic capacity. Not all social studies teachers are experts in government or civics. Social studies courses, especially in ninth-grade classrooms, typically survey a broad range of subjects, such as history, economics, geography, global studies, government, and civics, and it is unlikely that teachers would have received training in all subject areas (Baldi et al., 2001:25; Niemi and Junn, 1998; Niemi and Smith, 2001). In fact, researchers have found that teachers' content knowledge, or disciplinary training, impacts not just their curricular choices, but their instructional choices 
as well (Cuban, 1991; Wilson and Wineburg, 1988). Use of videos, therefore, can be a useful pedagogical approach to bringing civics expertise into the classroom. Teachers seem to agree, considering that nearly 75 percent of the distribution of this factor score falls in the highest category.

\section{Results}

We provide some context for the multivariate tests that follow by starting with the distribution of responses on the individual items that make up all four democratic capacity dependent variables. There is a fair amount of variance across the political knowledge items. Many students were able to correctly answer the following questions: whose rights the Bill of Rights addresses (77.1 percent), from where the powers of the president are derived (60.8 percent), and which amendment deals with cruel and unusual punishment (58.8 percent). A moderate number of students were able to correctly answer these questions: the nature of the rights described in the Constitution (43.8 percent), one purpose of the Fourth Amendment (43.8 percent), and whether judicial review is a function of the Court (41.6 percent). Very few students correctly answered what all NGOs have in common (27.7 percent) and the source of the number of electoral votes (25.9 percent). The average across all eight items is below a typical passing score if this were an exam (47.3 percent). While clearly these items do not address all the aspects or "nuts and bolts" components of American government one would expect to be taught in a civic education class, they do cover a broad range of topics. We believe that a student with a solid foundational knowledge of American government could respond correctly to more of these questions than one without that foundation. Thus, we contend that the index is a good measure of the general concept of political knowledge.

The variation is less dramatic across the other democratic capacity items. For the external efficacy items, aggregate responses range from 30.8 percent (either agreed or strongly agreed that the government quickly forgets voters' needs) to 44.2 percent (either agreed or strongly agreed that the government tries its best to find out what ordinary people want). A total of 35.9 and 42.6 percent, respectively, disagreed or strongly disagreed that only a few have a lot of power and that the government cares very little about the opinions of ordinary people. There is a bit more variation on the internal efficacy items. Only 25.6 percent agree or strongly agree that they know more about politics than most people their age while 60.8 percent agree or strongly agree that they usually have something to say in political discussions, and 62.3 percent agree or strongly agree that they are able understand political issues easily. Typical with survey results regarding turnout in the adult population, the results suggest that turnout will be higher among these young future voters than it will likely be if current patterns persist: 85.5 percent say they either probably or certainly plan to vote as an adult. 
The results of the first set of multivariate models that include the four instructional methods without combining them are presented in Table 2 . The most obvious conclusion that can be drawn from these results is that, with the exception of creating an open classroom climate, there is no consistency with the impact of the other three instructional methods across these four democratic capacity outcomes. Consistent with Campbell's $(2007,2008)$ findings, creating an open classroom climate that encourages student expression and debate has a positive effect. This positive relationship is clearly significant with each democratic capacity outcome, increasing the odds of being classified higher on the knowledge index by 1.41 times, the external efficacy index by 1.91 times, the internal efficacy index by 1.13 times, and the intent to vote by 1.73 times. These odds ratios are not as high as those presented in Gainous and Martens (2012), but the model specification here is different as is the measurement (using a factor score as opposed to an additive index). Nonetheless, the relationship is apparent.

As mentioned above, the same cannot be said for the other three instructional methods across all outcomes. Traditional teaching is positively related to external efficacy and the intent to vote $(p=0.08)$, increasing the odds of scoring higher on those outcomes, respectively, by 1.35 and 1.31 times. Active learning teaching methods are significantly related to the other two democratic capacity outcomes but, interestingly, they are negatively related to knowledge and positively related to internal efficacy (odds ratios $=0.77$, 1.44 , respectively). At first, the former finding may seem odd, but it actually makes quite a bit of sense. Teachers who are more likely to do things such as have their students write letters, role-play, and engage with community visitors are likely spending less time focusing on basic knowledge building simply because they have less classroom time available to do so. Further, in light of research discussed earlier that suggests different mechanisms may be at work in rote learning and student motivation, it is not surprising that we see some differentiation in pedagogical effects on knowledge and efficacy. It also makes sense that these types of active learning activities would stimulate internal efficacy because they compel students to get experience with the types of behaviors that are required for a highly engaged citizen. Thus, their confidence is bolstered. This latter result will become important in our discussion of the instructional method combination rankings. Finally, video teaching only has a positive effect on knowledge. As mentioned earlier, teachers may use video teaching to compensate for a lack of expertise. If this is the case, the result that video teaching increases the odds of being higher on the knowledge index by 1.28 times is logical.

Before moving to the ranking of the combined instructional methods, the effects of the control variables in Table 2 are worth noting. Not surprisingly, and consistent with Gainous and Martens (2012), there is a significant and positive effect of the frequency of social studies instruction across all the dependent variables with the exception of internal efficacy. The largest effect is on external efficacy (odds ratio $=2.17$ ), second on the intent to vote 
TABLE 2

The Effectiveness of Varied Instructional Methods

\begin{tabular}{|c|c|c|c|c|c|c|c|c|}
\hline & Knowledge & $\mathrm{O} / \mathrm{R}$ & $\begin{array}{l}\text { External } \\
\text { Efficacy }\end{array}$ & $\mathrm{O} / \mathrm{R}$ & $\begin{array}{l}\text { External } \\
\text { Efficacy }\end{array}$ & $\mathrm{O} / \mathrm{R}$ & $\begin{array}{l}\text { Plan/ } \\
\text { Vote }\end{array}$ & $\mathrm{O} / \mathrm{R}$ \\
\hline Trad teaching & $\begin{array}{c}-0.13 \\
(0.14)\end{array}$ & - & $\begin{array}{l}0.30^{*} \\
(0.13)\end{array}$ & 1.35 & $\begin{array}{c}0.14 \\
(0.14)\end{array}$ & - & $\begin{array}{c}0.27^{+} \\
(0.15)\end{array}$ & 1.31 \\
\hline Active learning & $\begin{array}{c}-0.26^{* *} \\
(0.09)\end{array}$ & 0.77 & $\begin{array}{c}0.11 \\
(0.09)\end{array}$ & - & $\begin{array}{l}0.37^{* *} \\
(0.09)\end{array}$ & 1.44 & $\begin{array}{c}-0.03 \\
(0.10)\end{array}$ & - \\
\hline Video teaching & $\begin{array}{c}0.25^{*} \\
(0.10)\end{array}$ & 1.28 & $\begin{array}{c}0.02 \\
(0.10)\end{array}$ & - & $\begin{array}{c}-0.02 \\
(0.10)\end{array}$ & - & $\begin{array}{c}0.15 \\
(0.12)\end{array}$ & - \\
\hline $\begin{array}{l}\text { Open } \\
\text { classroom }\end{array}$ & $\begin{array}{l}0.34^{* *} \\
(0.05)\end{array}$ & 1.41 & $\begin{array}{l}0.65^{* *} \\
(0.05)\end{array}$ & 1.91 & $\begin{array}{r}0.12^{*} \\
(0.05)\end{array}$ & 1.13 & $\begin{array}{l}0.55^{* *} \\
(0.05)\end{array}$ & 1.73 \\
\hline $\begin{array}{l}\text { Frequency/ } \\
\text { class }\end{array}$ & $\begin{array}{l}0.34^{* *} \\
(0.12)\end{array}$ & 1.41 & $\begin{array}{l}0.78^{* *} \\
(0.11)\end{array}$ & 2.17 & $\begin{array}{c}0.16 \\
(0.12)\end{array}$ & - & $\begin{array}{l}0.36^{* *} \\
(0.13)\end{array}$ & 1.43 \\
\hline Other SS & $\begin{array}{c}-0.10 \\
(0.09)\end{array}$ & - & $\begin{array}{c}0.02 \\
(0.09)\end{array}$ & - & $\begin{array}{r}-0.18^{*} \\
(0.09)\end{array}$ & 0.83 & $\begin{array}{c}-0.05 \\
(0.10)\end{array}$ & - \\
\hline $\begin{array}{l}\text { Curricular } \\
\text { breadth }\end{array}$ & $\begin{array}{r}0.35^{*} \\
(0.16)\end{array}$ & 1.41 & $\begin{array}{l}1.02^{* *} \\
(0.16)\end{array}$ & 2.77 & $\begin{array}{l}0.88^{* *} \\
(0.16)\end{array}$ & 2.41 & $\begin{array}{c}0.57^{* *} \\
(0.18)\end{array}$ & 1.77 \\
\hline School SES & $\begin{array}{c}-0.60^{* *} \\
(0.18)\end{array}$ & 0.55 & $\begin{array}{c}0.06 \\
(0.18)\end{array}$ & - & $\begin{array}{c}0.42^{*} \\
(0.18)\end{array}$ & 1.53 & $\begin{array}{c}-0.06 \\
(0.20)\end{array}$ & - \\
\hline $\begin{array}{l}\text { Civic } \\
\quad \text { engagement }\end{array}$ & $\begin{array}{c}-0.02 \\
(0.22)\end{array}$ & - & $\begin{array}{l}0.52^{*} \\
(0.23)\end{array}$ & 1.69 & $\begin{array}{l}1.32^{* *} \\
(0.22)\end{array}$ & 3.74 & $\begin{array}{l}0.61^{* *} \\
(0.25)\end{array}$ & 1.85 \\
\hline $\begin{array}{l}\text { Home } \\
\text { environment }\end{array}$ & $\begin{array}{l}4.15^{* *} \\
(0.26)\end{array}$ & 63.69 & $\begin{array}{c}0.35 \\
(0.26)\end{array}$ & - & $\begin{array}{l}4.28^{* *} \\
(0.27)\end{array}$ & 72.22 & $\begin{array}{l}4.23^{* *} \\
(0.31)\end{array}$ & 68.45 \\
\hline Female & $\begin{array}{c}0.05 \\
(0.07)\end{array}$ & - & $\begin{array}{c}-0.29^{* *} \\
(0.07)\end{array}$ & 0.75 & $\begin{array}{c}-0.64^{* *} \\
(0.07)\end{array}$ & 0.53 & $\begin{array}{c}0.21^{* *} \\
(0.08)\end{array}$ & 1.23 \\
\hline Latino & $\begin{array}{c}-0.07 \\
(0.10)\end{array}$ & - & $\begin{array}{c}-0.06 \\
(0.10)\end{array}$ & - & $\begin{array}{l}0.31^{* *} \\
(0.10)\end{array}$ & 1.37 & $\begin{array}{c}-0.31^{* *} \\
(0.12)\end{array}$ & 0.33 \\
\hline Black & $\begin{array}{c}-0.78^{* *} \\
(0.09)\end{array}$ & 0.46 & $\begin{array}{c}-0.43^{* *} \\
(0.09)\end{array}$ & 0.65 & $\begin{array}{l}0.41^{* *} \\
(0.09)\end{array}$ & 1.51 & $\begin{array}{c}-0.40^{* *} \\
(0.11)\end{array}$ & 0.67 \\
\hline $\begin{array}{l}\text { Pseudo } R^{2} \\
N=(2,615)\end{array}$ & 0.06 & & 0.05 & & 0.06 & & 0.12 & \\
\hline
\end{tabular}

NOTE: Data come from a 1999 national study conducted by the International Association for the Evaluation of Educational Achievement (IEA). Table entries are ordered-logit coefficients, associated standard errors in parentheses, and odds ratios for the statistically significant variables, ${ }^{*} p \leq 0.05 ;{ }^{* *} p \leq 0.01 ;{ }^{+} p \leq 0.10$.

(odds ratio $=1.43$ ), and third on knowledge (odds ratio $=1.41)$. Because social studies education at this level is often an amalgam of different academic subjects, including government, history, economics, global studies, and geography, we control for whether the social studies class focused directly on civics or government, which would arguably effect the quality of civics instruction to which students would be exposed. This variable is significant only in the internal efficacy model, suggesting that classes particularly dedicated to civics or government actually deter personal confidence (odds ratio $=0.83$ ). A puzzling finding, but perhaps students enrolled in such classes are more readily faced with their own limited understanding of how government works and this deters internal efficacy. Most importantly, the effects of the frequency of 
social studies instruction remain positive and significant while controlling for the type of social studies class. The number of civics topics covered, curricular breadth, has positive, significant effects on all four dependent variables: knowledge, external efficacy, internal efficacy, and intent to vote (odds ratios $=1.41$, $2.77,2.41,1.77)$. As demonstrated by Gainous and Martens (2012), covering more civics topics appears to be an effective means of generating democratic capacity and, most pertinent to this study, the teaching effects estimated are while controlling for this important factor.

The other control variables are all consistent with Gainous and Martens (2012) as well. School SES is a negative predictor of knowledge and positively related to internal efficacy (see Gainous and Martens (2012) for explanation), civic engagement is positively related to all but knowledge, home environment is positively related to all but external efficacy, and as Gainous and Martens (2012) focus on, is the largest effect in the models (see odds ratios). Finally, as for demographics, the odds that females are lower on the external and internal efficacy indices are 0.75 and 0.53 times greater than males, and the odds that females certainly plan to vote are 1.23 times higher than males. The odds are 1.37 times greater that Latinos are higher than races other than blacks (the reference category since blacks are included in the models) on the internal efficacy index, and 0.33 times greater that they certainly do not plan to vote. Blacks are 0.46 times more likely to be lower on the knowledge index than those who are a race other than Latino (again this is the reference category based on the specification of the models), the odds they are lower on the external efficacy index and the intent to vote indicator are roughly 0.7 times greater for both. Similar to Latinos, they are more likely to be classified higher on the internal efficacy index by 1.51 times.

The ranking results of the 44 models that estimated the effects of the 11 possible combinations of instructional methods are presented in Table 3. Again, these rankings are based on the size of the odds ratios for each respective combination of approaches. That means that for each of the four outcomes, we estimated a model for each respective combination of instructional approach while controlling for whatever instructional approach was not included in the index. The odds ratios for the indices in each model were then put in ascending order (details of the ranking system are provided in the note to Table 3). First, with the exception of six combinations, the effects were significant and positive on all four outcomes. There was one combination with a negative relationship in the knowledge model, active learning and traditional teaching. This is consistent with those findings regarding active learning discussed in Table 2. Second, none of the insignificant combinations included fostering an open classroom climate. Fostering an open classroom climate clearly seems to be driving which combinations are most effective. Those with the highest relative odds of being associated with an increase on the four democratic capacity outcomes all include open classroom. The top seven ranked combinations include an open classroom climate. In fact, there are no combinations without an open classroom climate that rank higher than those that have it included. This 
TABLE 3

The Optimal Combination of Instructional Methods

\begin{tabular}{lccrrr}
\hline & Overall & Knowledge & $\begin{array}{r}\text { External } \\
\text { Efficacy }\end{array}$ & $\begin{array}{r}\text { Internal } \\
\text { Efficacy }\end{array}$ & $\begin{array}{c}\text { Plan to } \\
\text { Vote }\end{array}$ \\
\hline OC/TT & 1 & $2(1.33)$ & $1(1.83)$ & $8(1.13)$ & $1(1.67)$ \\
OC/NT & 2 & $5(1.25)$ & $3(1.71)$ & $3(1.19)$ & $4(1.54)$ \\
OC/AL & 3 & $1(1.39)$ & $2(1.72)$ & $10(1.10)$ & $2(1.62)$ \\
OC/TT/AL & 4 & $6(1.20)$ & $4(1.67)$ & $4(1.18)$ & $5(1.51)$ \\
OC/TT/NT & 5 & $3(1.29)$ & $5(1.61)$ & $9(1.10)$ & $3(1.54)$ \\
OC/NT/AL & 6 & $4(1.25)$ & $6(1.58)$ & $6(1.16)$ & $6(1.47)$ \\
OC/TT/NT/AL & 7 & $7(1.20)$ & $7(1.51)$ & $7(1.14)$ & $7(1.43)$ \\
TT/AL & 8 & $11(-0.80)$ & $8(1.18)$ & $1(1.35)$ & $10(-)$ \\
VT/AL & 9 & $10(-)$ & $10(1.13)$ & $5(1.18)$ & $9(1.12)$ \\
TT/NT/AL & 10 & $9(-)$ & $11(-)$ & $2(1.23)$ & $11(-)$ \\
VT/TT & 11 & $8(-)$ & $9(1.14)$ & $11(-)$ & $8(1.22)$ \\
N=(2,615) & & & & & \\
\hline NOTE:OC & & & & & \\
\hline
\end{tabular}

NOTE: $\mathrm{OC}=$ open classroom climate; $\mathrm{VT}=$ video teaching; $\mathrm{TT}=$ traditional teaching; $\mathrm{AL}=\mathrm{ac}-$ tive learning. Odds ratios in parentheses, $(-)=$ not significant. $\mathrm{AL} / \mathrm{TT}$ had a negative relationship with knowledge and was ranked last for its effect on knowledge. An average of the odds ratios was used when there was a tie between OC/VT and OC/AL with the highest average odds ratio being ranked higher.

is consistent with the results from Table 2 that indicated an open classroom climate was the only instructional method that had a positive effect across all four democratic capacity outcomes. While earlier research indicated that an open classroom climate was important (Campbell, 2007, 2008; Gainous and Martens, 2012), it has not demonstrated that an open classroom seems to determine the effectiveness of other pedagogical approaches. That is exactly, however, what these results suggest. While we do not want to overemphasize the differences across the one-to-one comparisons in these combinations because, as evident in Table 3, the odds ratio differences are not extremely large, we do want to emphasize the general pattern here. Fostering an open classroom climate appears indispensable to generating democratic capacity.

The second notable finding in Table 3 is that the combination of approaches that seem to effectively stimulate knowledge, external efficacy, and the intent to vote vary greatly from those that do so for internal efficacy. Notice that the rank order for knowledge, external efficacy, and the voting intention outcomes are all very similar to each other and to the overall ranking (in fact, external efficacy is almost identical to the overall ranking). The rank ordering of the combinations that works best for internal efficacy is nearly inverted from the others and from the overall ranking. It seems that creating an open classroom climate may be less effective than active learning techniques at bolstering students' confidence than it is at generating positive outcomes for the other democratic capacity components. This is not to say that creating an open 
classroom has a negative effect on internal efficacy because, as demonstrated in the results in Table 2 and by the significant positive effect of all combinations including an open classroom, an open classroom generates internal efficacy, just not to the same degree as active learning techniques. In fact, the only highly ranked open classroom combination in the internal efficacy model is when it is combined with active learning teaching (\#3). Again, we do not want to overemphasize the one-to-one comparisons, but the pattern is evident. It seems that having students actually perform activities related to civics and government, such as writing letters, role-playing, and engaging with community leaders, builds confidence. That said, it is important to note that this result should not overshadow the fact, again, that creating an open classroom does have a positive effect on internal efficacy and seems to dominate as the most effective teaching method by itself or combined with any other approach for the other democratic capacity outcomes.

\section{Discussion}

The results here offer some interesting conclusions. First, the effects of various teaching methods employed in civics instruction on American youth are not consistent across all dimensions of what we call democratic capacity. Knowledge, external efficacy, and the intent to vote respond differently than internal efficacy to classroom effects. This is one of our most important findings. The goal of civic education is undoubtedly to create "good" citizens, but our research suggests that identifying "good" teaching may depend on your definition of "good" citizenship. As citizens, policymakers, and educators, we all hope to see future generations of well-informed and deeply engaged Americans graduate into citizenship, but we may need to prioritize our goals, recognizing that teachers may need to make instructional choices between building political knowledge and building political confidence in their students. This choice has already been anticipated by researchers discussed earlier, such as Kahne and Westheimer (2006), who counsel educators to be attentive to differences in pedagogical effects on external and internal efficacy. We expand upon that counsel by encouraging educators to be likewise attentive to instructional tradeoffs between creating the capacities for active and informed citizenship.

Second, we caution teachers against attempting to avoid these tradeoffs by expanding their instructional repertoires to include every combination of teaching techniques that favorably impacts democratic capacity. In light of Gainous and Martens's (2012) finding that the proliferation of teaching techniques employed in the classroom negatively impacts knowledge building, more is not necessarily better when it comes to instructional breadth. One of the benefits of the current study is that it provides teachers with guidance in matching their instructional approaches with their instructional goals, but it should not be taken as a means to circumvent hard choices that need to be 
made about which democratic outcomes to pursue most aggressively in their classroom.

Third, while the results here suggest that there may be some tradeoffs between stimulating knowledge, external efficacy, and the intent to vote with internal efficacy, it is apparent that earlier findings suggesting that creating an open classroom climate was important (Campbell, 2007, 2008; Gainous and Martens, 2012) were not only correct but, in fact, an open classroom climate seems to be the most influential teaching method for building effective citizenship. This is perhaps our most important contribution. Maintaining an open classroom climate not only best stimulates all elements of democratic capacity, but also generally makes all other instructional methods better when employed in combination. Despite these significant findings, more work can be done in this area. Specifically, it would be interesting to see just exactly what types of teachers are more likely to foster an open classroom climate. Are younger teachers more likely to do so? Does the political perspective (party identification and ideology) of a teacher determine how likely he or she is to employ such a method that relies on some degree of student empowerment? Also, are certain types of students more likely to respond to an open classroom? Are there racial and class differences? Campbell (2007) found that racial diversity in the classroom corresponds with lower levels of political discussion, but further research on race and open classrooms is warranted. For now, it is apparent that creating an open classroom climate is indispensable for generating democratic capacity. Considering the relatively low rate of adoption of this instructional method by social studies teachers, only about 10 percent were reported to robustly embrace student input in their classrooms, there is much room here to improve upon civic education's current effectiveness.

Fourth, given our finding that traditional teaching in combination with an open classroom is the most effective overall pedagogical approach to civic education, it turns out that most teachers are already on track to improve their students' democratic capacity, as traditional teaching remains the dominant instructional pattern in social studies teaching. Teachers do not necessarily need to completely revamp their classrooms or master a large number of popular new instructional techniques to get better results. Instead of adding more instructional activities to clutter up a class period, teachers comfortable with the traditional model of instruction may better serve their students by committing to welcoming their input and valuing their ideas.

Finally, we do not wish to be naïve in assuming that generating democratic capacity is the only concern that teachers have in mind when teaching civics, or that adoption of an open classroom is a simple matter. Instructional choices by teachers reflect not only an interest in positive learning outcomes, but also other concerns such as pleasing both administrators and students, maintaining discipline, ensuring students earn promotion, and preparing for standardized testing (Cuban, 1990; Thornton, 1994). In many cases, teachers rank pleasing students and maintaining classroom order ahead of curricular goals (McNeil, 1986; Thornton, 1994). Certainly, "good" democratic citizenship would not 
be successfully modeled in chaos, so we do not wish to push teachers to adopt teaching techniques that would undermine their classroom, make them uncomfortable given their disciplinary background or pedagogical outlook, or cause them to miss their testing targets, but for those teachers eager to build responsible young citizens, and who have the latitude from sympathetic parents and administrators to do so, we provide excellent guidance as to what works in the classroom.

In this study, we discovered that teachers teaching civics in America's ninthgrade classrooms tend to rely on four main teaching approaches: traditional teaching, active learning, video teaching, and maintenance of an open classroom climate, with traditional teaching far and away the most popular method. This fills important gaps in the existing empirical understanding of how teachers teach civics. While we found some variation in how these four teaching approaches impact democratic capacity, particularly internal efficacy as contrasted with knowledge, external efficacy, and voting intent outcomes, the unmistakable conclusion to be drawn from our research is that fostering an open classroom climate is the surest way to improve the democratic capacity of America's youth. Perhaps it is only right that in a democracy the best way to build young democrats is by valuing their input in the classroom just as we would value their input in the political arena.

\section{REFERENCES}

Almond, Gabriel A., and Sidney Verba. 1963. The Civic Culture; Political Attitudes and Democracy in Five Nations. Princeton, NJ: Princeton University Press.

Andolina, Molly W., Krista Jenkins, Cliff Zukin, and Scott Keeter. 2003. "Habits from Home, Lessons from School: Influences on Youth Civic Engagement." PS: Political Science and Politics 36(2):275-80.

Balch, George I. 1974. "Multiple Indicators in Survey Research: The Concept 'Sense of Political Efficacy'” Political Methodology 1:1-43.

Baldi, Stephane, Marianne Perie, Dan Skidmore, Elizabeth Greenberg, Carole Hahn, and Dawn Nelson. 2001. What Democracy Means to Ninth-Graders: U.S. Results from the International IEA Civic Education Study. Washington, DC: NCES 2001-096.

Beck, Paul Allen. 1977. “The Role of Agents in Political Socialization.” In Stanley Allen Renshon, ed., Handbook of Political Socialization: Theory and Research. New York: Free Press.

Benware, Carl A., and Edward L. Deci. 1984. "Quality of Learning with an Active Versus Passive Motivational Set." American Educational Research Journal 21(4):755-765.

Billig, Shelley, Sue Root, and Dan Jesse. 2005. The Impact of Participation in Service-Learning on High School Students' Civic Engagement. Medford, MA: CIRCLE (The Center for Information and Research on Civic Learning and Engagement).

Bonwell, Charles C., and James A. Eison. 1991. Active Learning: Creating Excitement in the Classroom. Washington, DC: George Washington University Clearinghouse on Higher Education.

Campbell, David E. 2007."Sticking Together: Classroom Diversity and Civic Education.” American Politics Research 35(1):57-78. 
2008. "Voice in the Classroom: How an Open Classroom Climate Fosters Political Engagement Among Adolescents." Political Behavior 30(4):437-54.

Conover, Pamela Johnston, and Donald D. Searing. 2000. "A Political Socialization Perspective.” Pp. 91-124 in Lorraine McDonnell, P. Michael Timpane, and Roger W. Benjamin, eds., Rediscovering the Democratic Purposes of Education. Lawrence: University Press of Kansas.

Converse, Philip E. 1972. "Change in the American Electorate." Pp. 263-337 in Angus Campbell and Philip E. Converse, eds., The Human Meaning of Social Change. New York: Russell Sage Foundation.

Crabtree, Steve. 2005. Americans' Education Priorities Start with the Basics, Gallup. Available at $<$ http://www.gallup.com/poll/14779/americans-education-priorities-start-basics.aspx>.

Cuban, Larry. 1990. "What I Learned from What I Had Forgotten About Teaching: Notes from a Professor." Phi Delta Kappan 71:479-82.

1991. "History of Teaching in Social Studies." In James P. Shaver, ed., Handbook of Research on Social Studies Teaching and Learning. New York: Macmillan.

Delli Carpini, Michael X. 2000. "Gen.Com: Youth, Civic Engagement, and the New Information Environment.” Political Communication 17(4):341-49.

Delli Carpini, Michael X., and Scott Keeter. 1996. What Americans Know About Politics and Why It Matters. New Haven: Yale University Press.

Dempster, A. P., N. M. Laird, and D. B. Rubin. 1977. "Maximum Likelihood from Incomplete Data via the Em Algorithm." Journal of the Royal Statistical Society. Series B (Methodological) 39(1):1-38.

Easton, David, and Jack Dennis. 1969. Children in the Political System: Origins of Political Legitimacy. Mcgraw-Hill Series in Political Science. New York: McGraw-Hill.

Ehman, Lee H. 1980. “Change in High School Students' Political Attitudes as a Function of Social Studies Classroom Climate.” American Educational Research Journal 17(2):253-65.

Feldman, Lauren, Josh Pasek, Daniel Romer, and Kathleen H. Jamieson. 2007. "Identifying Best Practices in Civic Education: Lessons from the Student Voices Program." American Journal of Education 114(1):75-100.

Gainous, Jason, and Allison M. Martens. 2012. "The Effectiveness of Civic Education: Are 'Good' Teachers Actually Good for 'All' Students?” American Politics Research 40(2):23266.

Gimpel, James G., J. Celeste Lay, and Jason E. Schuknecht. 2003. Cultivating Democracy: Civic Environments and Political Socialization in America. Washington, DC: Brookings Institution Press.

Godwin, R. Kenneth, and Frank R. Kemerer. 2002. School Choice Tradeoffs: Liberty, Equity, and Diversity, 1st ed. Austin: University of Texas Press.

Hahn, Carole. 1998. Becoming Political: Comparative Perspectives on Citizenship Education. Albany: State University of New York Press.

Hart, Daniel, Thomas M. Donnelly, James Youniss, and Robert Atkins. 2007. "High School Community Service as a Predictor of Adult Voting and Volunteering." American Educational Research Journal 44(1):197-219.

Hartry, Ardice, and Kristie Porter. 2004. We the People Curriculum: Results of Pilot Test. Calabasas, CA: Center for Civic Education (CCE).

Hess, Diana E. 2004. "Controversies About Controversial Issues in Democratic Education." PS: Political Science \& Politics 37(02):257-61. 
Hess, Diana E., and Julie Posselt. 2002. "How High School Students Experience and Learn from the Discussion of Controversial Public Issues." Journal of Curriculum and Supervision 17(4):283-314.

Hess, Robert D., and Judith Torney-Purta. 1967. The Development of Political Attitudes in Children. Chicago: Aldine Pub. Co.

Hibbing, John R., and Elizabeth Theiss-Morse. 1996. "Civics Is Not Enough: Teaching Barbarics in K-12." PS: Political Science and Politics 29(1):57-62.

. 2002. Stealth Democracy: Americans'Beliefs About How Government Should Work. New York: Cambridge University Press.

Jennings, M. Kent, and Richard G. Niemi. 1974. The Political Character of Adolescence: The Influence of Families and Schools. Princeton, NJ: Princeton University Press.

Junn, Jane. 2004. "Diversity, Immigration, and the Politics of Civic Education." PS: Political Science \& Politics 37(02):253-55.

Kaestle, Carl F., and Eric Foner. 1983. Pillars of the Republic: Common Schools and American Society, 1780-1860. New York: Hill and Wang.

Kahne, Joseph E., Bernadette Chi, and Ellen Middaugh. 2006. "Building Social Capital for Civic and Political Engagement: The Potential of High-School Civics Courses." Canadian Journal of Education 29(2):387-409.

Kahne, Joseph E., and Susan E. Sporte. 2008. "Developing Citizens: The Impact of Civic Learning Opportunities on Students' Commitment to Civic Participation." American Educational Research Journal 45(3):738-766.

Kahne, Joseph E., and Joel Westheimer. 2006. "The Limits of Political Efficacy: Educating Citizens for a Democratic Society." PS: Political Science \& Politics 39(02):289-96.

Langton, Kenneth P., and M. Kent Jennings. 1968. "Political Socialization and the High School Civics Curriculum in the United States." American Political Science Review 62(3):852-67.

Little, Roderick J. A., and Donald B. Rubin. 1987. Statistical Analysis with Missing Data. Wiley Series in Probability and Mathematical Statistics Applied Probability and Statistics. New York: Wiley.

Lopez, Mark Hugo, Peter Levine, Deborah Both, Abby Kiesa, Emily Kirby, and Karlo Marcelo. 2006. The 2006 Civic and Political Health of the Nation: A Detailed Look at How Youth Participate in Politics and Communities. Medford, MA: CIRCLE (The Center for Information and Research on Civic Learning and Engagement).

Macedo, Stephen. 2000. Diversity and Distrust : Civic Education in a Multicultural Democracy. Cambridge, MA: Harvard University Press.

McDevitt, Michael, and Spiro Kiousis. 2006. "Deliberative Learning: An Evaluative Approach to Interactive Civic Education." Communication Education 55:247-64.

McLachlan, Geoffrey J., and T. Krishnan. 1997. The Em Algorithm and Extensions. Wiley Series in Probability and Statistics Applied Probability and Statistics. New York: Wiley.

McNeil, Linda M. 1986. Contradictions of Control: School Structure and School Knowledge. New York: Routledge \& K. Paul.

Merelman, Richard M. 1971. Political Socialization and Educational Climates; A Study of Two School Districts. New York: Holt.

National Center for Education Statistics (NCES). 2011. The Nation's Report Card: Civics 2010 (NCES 2011-466). Washington, DC: Institute of Education Sciences, U.S. Department of Education. 
Niemi, Richard G., Mary A. Hepburn, and Chris Chapman. 2000. "Community Service by High School Students: A Cure for Civic Ills?” Political Behavior 22(1):45-69.

Niemi, Richard G., and Jane Junn. 1998. Civic Education: What Makes Students Learn. New Haven: Yale University Press.

Niemi, Richard G., and Julia Smith. 2001. "Enrollments in High School Government Classes: Are We Short-Changing Both Citizenship and Political Science Training?" PS: Political Science and Politics 34(2):281-87.

Niemi, Richard G., and Barbara I. Sobieszek. 1977. "Political Socialization." Annual Review of Sociology 3:209-33.

O'Connor, Sandra Day. 2011. Statement on the Nation's Report Card: Naep 2010 Civics [Press Release]. Washington, DC: National Assessment Governing Board.

Pasek, Josh, Lauren Feldman, Daniel Romer, and Kathleen Hall Jamieson. 2008. "Schools as Incubators of Democratic Participation: Building Long-Term Political Efficacy with Civic Education." Applied Developmental Science 12(1):26-37.

Rose, Lowell C., and Alec M. Gallup. 2000. "The 32nd Annual Phi Delta Kappa/Gallup Poll of the Public's Attitudes Toward the Public Schools." Phi Delta Kappan 82(1):41-58.

Schafer, J. L. 1997. Analysis of Incomplete Multivariate Data. Monographs on Statistics and Applied Probability. Boca Raton: Chapman \& Hall.

Silberman, Melvin L. 1996. Active Learning : 101 Strategies to Teach Any Subject. Boston: Allyn and Bacon.

Somit, Albert, Joseph Tanenhaus, Walter H. Wilke, and Rita W. Cooley. 1958. "Teaching Note: The Effect of the Introductory Political Science Course on Student Attitudes Toward Personal Political Participation." American Political Science Review 52(4):1129-32.

Thornton, Stephen J. 1994. “The Social Studies Near Century's End: Reconsidering Patterns of Curriculum and Instruction." Review of Research in Education 20:223-54.

2005. Teaching Social Studies That Matters: Curriculum for Active Learning. New York: Teachers College Press.

Torney-Purta, Judith. 2002. "The School's Role in Developing Civic Engagement: A Study of Adolescents in Twenty-Eight Countries." Applied Developmental Science 6(4):20312.

Turnbull, Jennifer, Susan Root, Shelley Billig, and Dawn Jaramillo. 2007. We the People. Evaluation Report. Calabasas, CA: Center for Civic Education (CCE).

Vercellotti, Tim, and Elizabeth C. Matto. 2010. The Classroom-Kitchen Table Connection: The Effects of Political Discussion on Youth Knowledge and Efficacy. Medford, MA: CIRCLE (The Center for Information and Research on Civic Learning and Engagement).

Wilson, Suzanne, and Samuel Wineburg. 1988. "Peering at History Through Different Lenses: The Role of Disciplinary Perspectives in Teaching History." Teachers College Record 89(4):52539.

Woolever, Roberta M., and Kathryn P. Scott. 1988. Active Learning in Social Studies: Promoting Cognitive and Social Growth. Glenview, IL: Scott, Foresman/Little, Brown College Division1988.

Youniss, James, and Miranda Yates. 1997. Community Service and Social Responsibility in Youth. Chicago, IL: University of Chicago Press.

Zmuda, Allison. 2008. “Springing into Active Learning.” Educational Leadership 66(3): 38-42. 